\section{ADJECTIVE PHRASES IN THE PREFACE OF AL-MUNJIDU DICTIONARY FIRST PRINTING WORKS LOUIS MA'LŪF AL- YASÜ'I: SYNTAX ANALYSIS}

\author{
Arief Fiddienika \\ Universitas Negeri Makassar \\ Email: arieffiddienika@unm.ac.id
}

Abstrak. Sebuah diskusi tentang sintaksis Arab dalam penelitian ini berfokus pada frase kata sifat dalam teks Kata Pengantar Kamus Al-Munjidu Karya Percetakan Pertama Louis Ma'lu>f Al-Yasu>'i. Penelitian ini mengungkapkan apakah dalam teks terdapat beberapa jenis frase kata sifat, bagaimana perbedaan frasa kata sifat ditemukan, dan bagaimana fungsi frasa kata sifat dalam sebuah kalimat, dan bagaimana membentuk "declesion" dari kata sifat frasa dalam sebuah kalimat.

Keywords: Frasa, Frasa Kata sifat, Pendahuluan Kamus al-Munjidu
INTERFERENCE Journal of Language, Literature, and Linguistics

Submitted: January $6^{\text {th }}, 2020$

Accepted : February $8^{\text {th }}, 2020$

Abstract. A discussion of Arabic syntax in this study focused on the adjective phrase in a text Preface of Al-Munjidu Dictionary First Printing Works Louis Ma'lu>f Al-Yasu>'i. This study reveals whether in the text there are several types of adjective phrases in the text, how the differences of the adjective phrase is found, and how the functions of the adjective phrases in a sentence, and how to form "declesion" of the adjective phrase in a sentence. 


\section{INTRODUCTION}

In view of linguistics, language is a symbol system sounds arbitrary and meaningless and serves as a means of communication. As the sound of the arbitrary symbol system, the intention is that the language is not mandatory or essential relationship between the symbol as a mark entities or lexeme words with objects marked, the referent of the word or lexeme (Chaer, 2002). Language as a means of communication consists of two parts, namely the form and meaning (Ramlan, 1985). Form of language is part of the language that consists of segmental elements and supra segmental elements. Segmental elements of language are hierarchically composed of discourse, sentence, clause, phrase, word, and morpheme. The supra segmental elements consist of intonation and subordinate elements, namely pressure (hard-soft), pitch (high-low), and duration (long-short). The meaning is the content that is contained in the forms it can cause certain reactions. Reactions that can arise due to hear or read a series of words make up a particular phrase, clause, sentence, or discourse.

Talking about the syntax, Kridalaksana says in his book "Kamus Linguistik" (Kridalaksana, 2001) that syntax is the setting and the relationship between words with words, or with a larger unit, or between units was greater in the language. Phrase is one study of syntax. The phrase commonly defined as a combined unit of grammatical form that is non-predicative word or combination of words commonly also called the fill one syntactic function in the sentence (Chaer, 2007). One form of the Arabic phrase is at-tarkību al-wasfy (phrases adjectives). Adjective is a word called after the noun indicating the object related conditions (Ghulayaini, 2006).

Arabic is the language of Semit sub of Hamito-Semit or Afro-Asiatic (Dalby, 2004). This language is included in the classical language of the most widely used in the world than the other classical languages such as Latin, Sanskrit, Hebrew, and others because it is the language of the Qur'an read by millions of Muslims all over the world, which is then used in the writing and discussion of issues that are related to religion.

Arabic speakers are estimated currently about 200 million people (Holes, 2004). Arabic is also the official language of twenty countries known as the Arabian Peninsula, located in a region stretching from West Asia to North Africa, and a country, Palestine, where Hebrew is the first official language and Arabic is the second language. The twenty countries are Morocco, Algeria, Mauritania, Tunisia, Libya, Sudan, Egypt, Djibouti, Somalia, Saudi Arabia, Kuwait, Bahrain, Qatar, the United Arab Emirates, Oman, Yemen, Jordan, Syria, Iraq, and Lebanon.

Various forms of the use of the phrase in Arabic can be seen in the texts in Arabic. That is usually arranged alphabetically followed by information about the meaning, usage, or translation. Al-Munjidu dictionary is one of the famous Arabic dictionaries. In this study, researchers will discuss the form of adjective phrases contained in the preface to Al-Munjidu Dictionary first printed work of Louis Ma'lüf Al-Yasū'i. 


\section{RESEARCH METHOD}

Method, in linguistic research is the unity of the series of processes includes: determining a frame of mind, the formulation of hypotheses or formulation of the problem, the determination of the population, sampling, data, techniques of data acquisition, and data analysis (Subroto, 1992). In an effort to solve the problem, this research was conducted to pass three stages of strategy, the stage providing data, analyzing stage data, and presenting the results of the data analysis phase (Sudaryanto, 1993). The first method used in this study is the library research method. Data in the form of adjective phrases and then analyzed further using syntax analysis and produce various forms of adjective phrases contained within the text. This method is the second study. The last method of this study is to provide a conclusion based on the analysis that has been carried out the last of the study.

\section{RESULT AND DISCUSSION}

Syntax is a grammar that examines the relationship between the words in the speech. The grammar is composed of morphology and syntax. If morphology concerns the grammatical structure in the word, the syntax concerns the grammatical structure of the words in the speech. One unit of speech is the sentence. The sentence is a unit that is a whole with a particular intonation as a marker of whole. Orthographically, the end of this sentence symbolized with a period, exclamation point, or question mark. Discussion about syntactic related with syntactic functions (subject, predicate, and object), syntactic roles (actor, patient), and the syntactic categories (nouns, verbs, particles)(Verhaar, 2008). In Arabic syntax better known as 'ilmu an-nahwi or 'ilmu al-i'rab, and understanding of nahwu itself is the rules and the definition of each word in the sentence, marking the end of words, and how is the word final shape (Ni'mah, 2019).

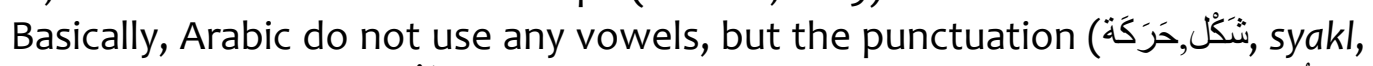

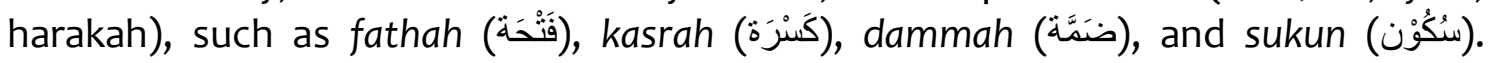
Consonants was read with certain rules. Arabic Morphology (sarf) and Arabic syntax (nahwu) as a guide in reading Arabic consonants. The readings consonants morphologically are done arbitrarily according pronunciation by Arabs (سِيَّاعِيَّ, sima'iy). The morphological readings are waged on consonants that are not located at the end of the word. For the consonants that are located at the end of words, syntactic readings are done. Syntactic readings related to the decletion (i'rab, إعْرَاب ), the change at the end of the word because of the inclusion of certain factors in a speech unit. Decletion consists of four different cases, namely nominative (رَفْع ( raf'), accusative (نَصنب , nasb), genitive (جَرَ , jazm) (Ghulayaini, 2006; Haywood \& Nahmad, 1965; Ryding, 2005).

The words in Arabic are divided into three, namely nouns ( إسنْ , ism),

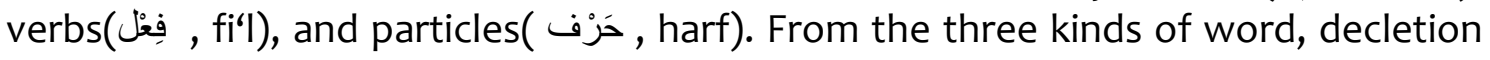
only occur in nouns and verbs. However, of all the nouns and verbs, some do not experience decletion. Nouns and verbs that do not experiencing decletion called mabniy ( مَنْنيّ ), while the nouns and verbs that are experiencing decletion called

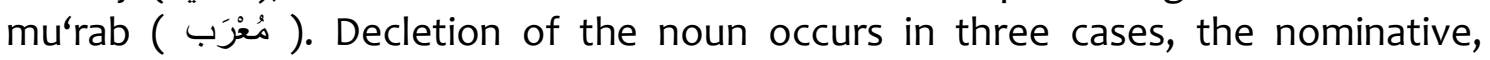
accusative, and genitive, while the decletion in verb also occurred in three cases, 
the nominative, accusative, and jussive, while the particles are always mabniy (Ghulayaini, 2006). Decletion cases on every word can be identified of the signs and each case has its own signs, with nouns and verbs having decletion in accordance with its function in the sentence. The first decletion is nominative (رَفَ, raf'). Nominative case has four marks, is dammah ('), wawu (و), alif ('), and nun(ن). The second is the accusative (نَصنب), which has five signs such as fathah ( ), alif ( 1 ), kasrah (-), ya' ( ي ), and deletion of nun (حَذْف النُّنْن). The third is the genitive (جر). Genitive case has three signs, namely kasrah (.), ya '(ي) and fathah ( ).

The phrase is a group of words that are a functional part of a longer speech and does not contain the predicate, and has a function as constituents in the longer form of the constituent clauses. Phrase consists of two parts, the stem and the attributes (Verhaar, 2008). Adjektive phrase (next called an AP) is the attribute form of adjective (صفة, sifah). If the attribute is an adjective (صفة), the stem is called mausuf (موصوف, ore attributed) or in Arabic is also called as (نعت, na'tun). Thus, the AP (التركيب الوصفي) consists of sifah and mausuf. Mausuf in the phrases above is in form of masculine singular word (المفرد المذكر), so sifah is also the same. If mausuf in form of words of different categories, then sifah also change, for example:

بيتان جميلان

'baitāni jamīlani'

'two good house'.

In AP there are some rules associated with masculine (المذكر) and feminine (المؤنث), definite (المعرفة) and indefinite (النكرة), singular (المثرد), dual (المفرد), and plural (الجمع), and the nominative (الرفع), accusative (النصب), and genitive (الجرة). In general, the rules are as follow. First, if mausuf has masculine category, then sifah has masculine too vice versa. Second, if mausuf has definite category, then sifah has definite too vice versa. Third, if mausuf has categorized singular, then sifah also singular. Similarly, if mausuf a categorized dual or plural. Lastly, if mausuf has categorized nominative, then sifah also has nominative. Likewise, if mausuf categorized accusative or genitive(Haywood \& Nahmad, 1965; Jarim \& Amin, 1966). So, Sifah itself does not have functions in the level of syntactic because the function will follow mausuf as a whole in the adjective phrase. Functions of adjective phrases can be either rafa' 'nominative' (if it has a role as an subject) and nasab 'accusative' (if it has a role as a object)(Ghulayaini, 2006).

In the preface to Al-Munjid Dictionary by Louis Ma'lūf there are some sentences that have an element of AP. Therefore, this data will be analyzed from the syntactic level of how the function of AP forms and its role. Categories are not included in this study because the category of the AP itself is known to be a combination of two nouns-turned phrase. In this text, there are twelve AP patterns, but in this study only analyzed five patterns because within twelve existing phrases some have the same pattern. So, this study only focused on the different patterns thus get better results.

1. إن أدباء آللغة العربية وائمنها العاملين في إعلاء شأنها (Data 1)

/Fa'inna udabā'a al-lugati al-'arabiyyati wa a'immatihā al-'āmilinna fĩ i'lā'i sya'niha/ 
'Surely the experts and specialists in the Arabic language that have been developed to uphold it is condition or existence'.

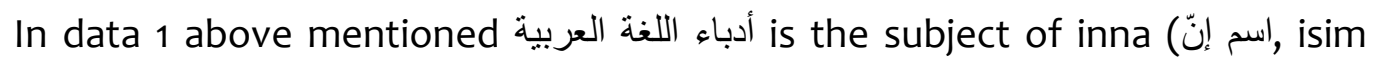

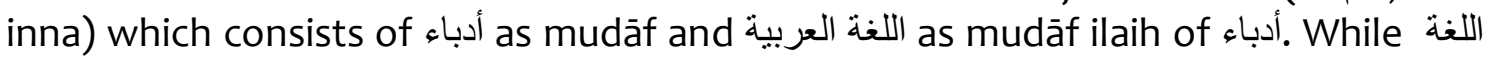
is a form of AP and the decletion of AP (_) is decletion for (مضاف العربية, إلياء ilaih). The function of the sentence above is described as follows.

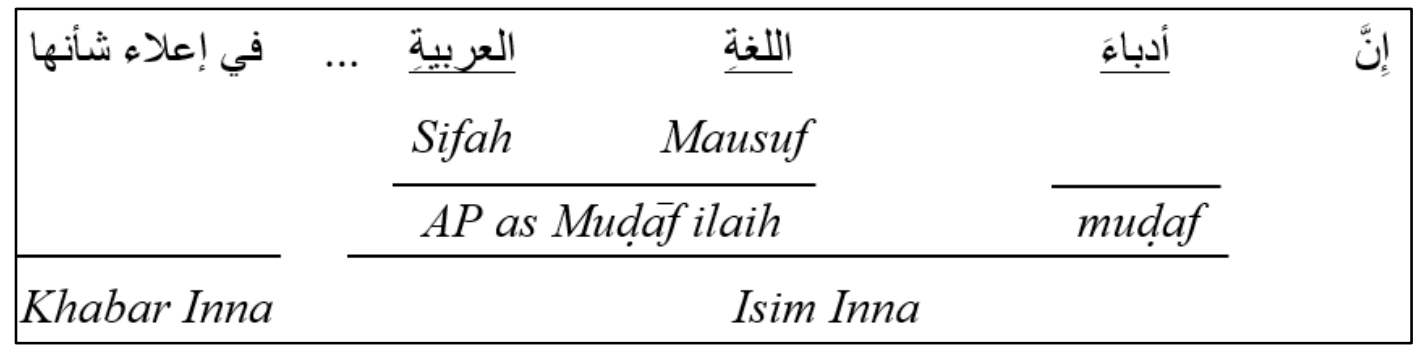

Table 1. First data analysis

In the data 1, the forms of AP can be replaced by another singular word.

إن أدباءً الجغر افيّ و أنمتها العاملين في إعلاء شأنها

/Fa'inna udabā'a al-jugrāfiyyi wa a'immatihā al-'āmilīna fĩ i'lā'i sya'niha/

'Surely the experts and geographers who have developed to uphold the condition and existence'.

So in the analysis above it can be concluded that the shape of the AP can be mudäf ilaih category within the function as subject of inna when combined with it's mudaf, and the AP can be replaced with another word. اللغة العربية as a noun replaced by الجغر افي. Both have different shapes, اللغة العربية is an AP and الجغر افية shaped in form of words. Both can be swapped and its function in the sentence remains the same as mudäf ilaih in the subject of inna. This can be seen when the word is experiencing the same decletions with genitive marked genitive decletion (جر) marking with (_) at the end of the word.

2. فذه الأزمنة بمسيس الحاجة إلى معجم مدرسيّ (Data 2)

/fī hādihī al-azminati bimasīsi al-ḥājati ilā mu'jami madrasiyyi/

'At this time desire to open a dictionary lesson is truly diligent'

In data 2, the AP is dative because it is located after abrative and the fungtion is adverb of place and the decletion of AP (_) is decletion for (اسم مجرور), isim majrur).

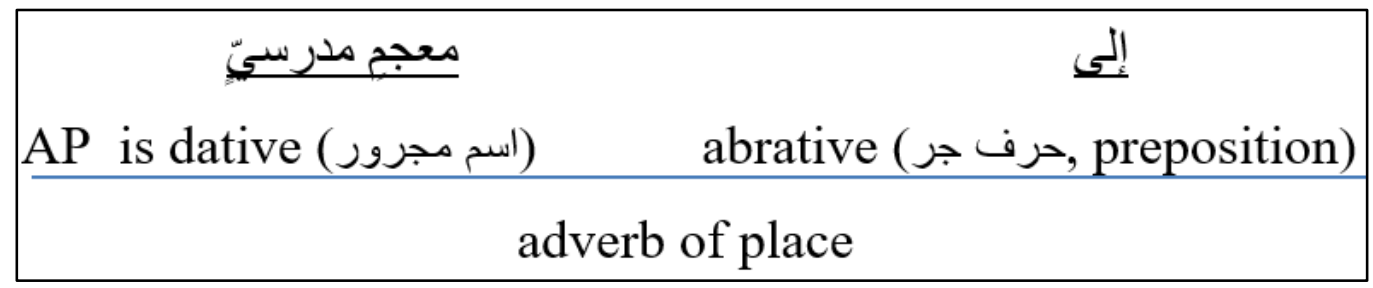


Table 2. Second data analysis

In the form above, AP can be replaced with another category.

في هذه الأزمنة بمسيس الحاجة إلى كلية

/fī hāòihì al-azminati bimasīsi al-hājati ilā kuliyyatin/

'At this time desire to open study is truly diligent'.

So, in the analysis above it can be concluded that the AP can be dative and can be replaced with another word category on condition of being in the same

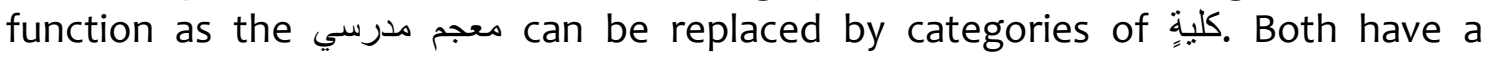
different form, معجم مدرسي has form AP and كلية in form of words. Both can be swapped, but its function in the sentence will remain with namely as dative of the adverb of place. This can be seen when the word is experiencing the same decletions with genitive marked genitive decletion (جر) marking with kasrah () at the end of the word.

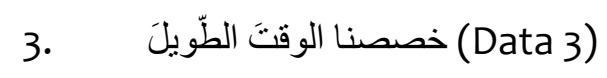

/Khașaṣnā al-waqta aț-țawīlal

'We have providing a long time'.

In data 3 function of AP is objects because it is located after verb and subject and the decletion of AP (مفعول به, maf'u>l bih).

\begin{tabular}{|c|c|c|}
\hline الوقتَّ الطَّويلَ & نا & خصص \\
\hline $\mathrm{AP}$ as Object & Subject & predicate \\
\hline
\end{tabular}

Table 3. Third data analysis

In the form above, the function of AP as object and can be replaced by other categories.

خصصنا النَّظرَيَّةًَ

/Khașașnā an-naḍariyyata/

'We have specialized in the theory'.

So, in the third data analysis it can be concluded that the form of the AP can function as an object in the verb sentences and categories can be replaced with another word category on condition of being in the same function as الوقت الطويل that can be replaced with النظرية. Both are different, الوقت الطويل is a form of AP and النظرية is a form of word. Both are interchangeable in this sentence, but its function in the sentence would remain the same, ie as objects. It can be seen from the end of an accusative decletion word (نَصْب) marking with (ن) at the end of the word.

4. ل لهم القولُ الصَّائبُُ

/Lahum al-qaulu aṣ-șā ìbu/

'The word that is easy to understand is theirs'. 
The previous data is a form of AP which has a function as subject in nominal sentence (مبند, mubtada') that were located at the end of the sentence muakhkhar is predicate of a nominal sentence (خبر and (مؤخر), khabar) that were locater at the first of the sentence muqaddam (مقدم). The subject in nominal sentence has nominative decletion with ( $)$ in the end of the phrase.

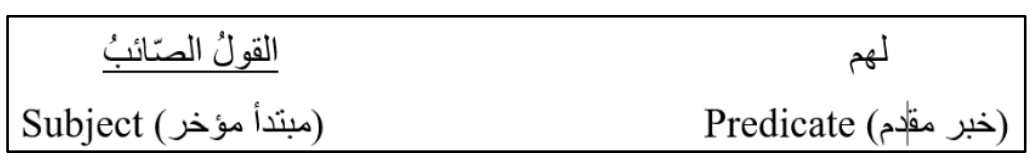

Table 4. Fourth data analysis

In the form above, the AP that has a function as a subject can be replaced with another noun category.

لهم القلمُ

/lahum al-qalamu/

'The pen is their'.

So, in the analysis of the data 4 it can be concluded that the AP has a function as a subject in the nominal sentence can be replaced with another word category on condition of being in the same function, as well as القول الصائب that is replaced with the word القلم. Both are different forms but have the same function, namely as a subject in a nominal sentence with nominative declention which is characterized by (s) at the end of the word.

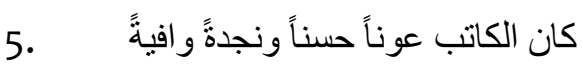

/Kāna al-kātibu 'awnan hasanan wa najdatan wäfìatan/

'Previously, the author had the good help and get adequate improvement'

In the latest data, there are two AP, عونا حسنا and نجدة وافية. Both have a function as the predicate of the kāna sentence (خبر كان), so have decletion accusative with a sign at the end of letters. Both can work together because there wawu atf fall between the APs, so the function of both are same. It is similar to English and Indonesian that the particle 'and' will make the function of the particle being equal, it is also the case in Arabic.

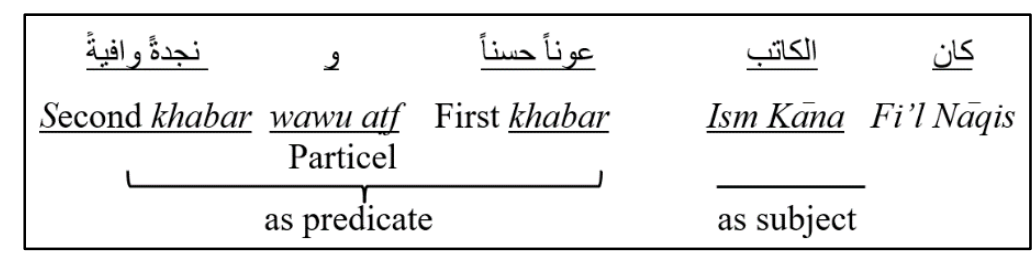

Table 5. Fifth data analysis

In the previous form, two APs function as a predicate and flanked by wawu atf can be replaced by other categories with the condition that the function has remained the same. 
كان الكاتب جاملاً وغنياً

/Kāna al-kātibu Jāmilan wa ganiyyan/

'Previously, the author was handsome and rich'.

So, in the analysis of the data 5 it can be concluded that the two APs function as a predicate located between wawu atf, can be replaced with another word category on condition of being in the same function as عونا حسنا ونجدة و افية replaced with جاملا و غنيا. Both of which are a different form, but have the same function, that is as a predicate run into accusative declention which is characterized by () at the end of the word.

\section{CONCLUSION}

Based on the previous presentation it can be concluded that the preface of Al-Munjidu Dictionary first printed work of Louis Ma'lūf Al-Yasū'i is a text form that can be analyzed from the point of syntactic and focusing on adjective phrase. The syntactical can be seen from the presence of some form of adjective phrases, both of which act as a subject, predicate, and object in the sentence. This was proven by the discovery of various forms of adjectives phrases in this preface of al-Munjīdu dictionary. In the text Preface Al-Munjidu Dictionary first printed work of Louis Ma'lūf Al-Yasū'i found five kinds functions of adjective phrases and described as follows.

1. AP can be categorized mudaf ilaihi in function as the subject of inna when combined with mudaf. In this form, adjective phrase can be replaced by other forms of nouns either it is singular, dual, and plural with the terms of the function of the AP with the condition it is still the same as run into genitive declension and marked with (9).

2. AP can be dative and can be replaced with another word category on condition of being in the same function. Both can be swapped, but its function in the sentence will remain with namely as dative of the adverb of place. This can be seen when the word is experiencing the same decletions with genitive marked genitive decletion (ج) marking with (9) at the end of the word.

3. The form of the AP can function as an object in the verbal sentences and its form can be replaced with another word on condition of the same function, as objects. It can be seen from the end of a word that had to be marked accusative decletion (نَصْب ) marking with (1) at the end of the word.

4. The Adjective phrase has a function as a subject in the nominal sentence can be replaced with another word category on condition of being in the same function as a subject in a nominal sentence with nominative declention which is characterized by ( $)$ at the end of the word.

5. The two AP function as a predicate in käna sentence and located between wawu at tf, can be replaced with another word category on condition of being in the same function. That is as a predicate run into accusative declention which is characterized by (j) at the end of the word. 
6. All forms of the adjective phrase, the category can be replaced with another category provided that the category function remains the same and did not change its position in the sentence.

\section{REFERENCES}

Chaer, A. (2002). Pengantar Semantik Bahasa Indonesia. Jakarta: Rineka Cipta.

Chaer, A. (2007). Linguistik Umum. Jakarta: PT Rineka Cipta.

Dalby, A. (2004). Dictionary of Language: The Definitive Reference to more than 400 Languages. London: A \& C Black.

Ghulayaini, M. (2006). Jamiu ad-Durus al-Arabiyyah. Beirut: Daar al-Fikr.

Haywood, J. A., \& Nahmad, H. M. (1965). A New Arabic Grammar of Written Language. London: ercy Lund, Humphiries \& c.o. Ltd.

Holes, C. (2004). Modern Arabic: Structures, Functions, and Varieties. Washington: Georgetown University Press.

Jarim, A., \& Amin, M. (1966). al-Balaghatu al-Wadihah. Cairo: Daar Al-Ma'arif.

Kridalaksana, H. (2001). Kamus Linguistik. Jakarta: PT Gramedia Pustaka Utama.

Ni'mah, F. (2019). At-Tuhfatu al-Bahiyyatu 'ala Mulakhkhasi Qawaidi al-Lughati al'Arabiyyati. Jakarta: Pustaka Al-Wadi.

Ramlan. (1985). Tata Bahasa Indonesia: Penggolongan Kata. Yogyakarta: Andi Offset.

Ryding, K. C. (2005). A Reference Grammar of Modern Standard Arabic. In A Reference Grammar of Modern Standard Arabic. https://doi.org/10.1017/CBO9780511486975

Subroto, E. (1992). Pengantar Metode Penelitian Linguistik Struktural. Surakarta: Sebelas Maret University Press.

Sudaryanto. (1993). Metode dan Aneka Teknik Analisis Bahasa: Pengantar Penelitian Wahana Kebudayaan Secara Linguis. Yogyakarta: Duta Wacana University Press.

Verhaar, J. W. M. (2008). Asas-Asas Linguistik Umum. Yogyakarta: Gadjah Mada University Press. 